\title{
The Contemporary Value of Environmental Protection Law.
}

\author{
Qingyu Tan ${ }^{\mathrm{a}}$, Hongzhou Shen ${ }^{\mathrm{b}}$ and Sisi $\mathrm{Li}^{\mathrm{c}}$ \\ School of Shanxi University of Finance and Economics, Taiyuan 030000, China; \\ a996068177@QQ.com, b1032300182@QQ.com, c53546687@QQ.com
}

Keywords: environmental law; value; pollution; protection.

\begin{abstract}
Horse philosophy tells us that practice decision knowledge, understanding of practice has the opposite effect. Any of the legal department is the product of the certain social historical conditions, therefore, in the field of environmental protection, people's understanding. In the long human society, people's awareness of environmental protection has experienced from scratch, distinguished process.
\end{abstract}

\section{Introduction}

The value of environmental law is the embodiment of law's value problem in the field of environmental law [1]. The value of the law is the property that the finger-pointing can satisfy the needs of the person as the subject or in accordance with the need. The main body of the law is human, which is the general term of social people. Method is the object of the value of the law itself, this law refers to the method of generalized, namely the floorboard of the legal norms and legal facts, it includes the method of the operation of the system, method of fact and in the form of the concept of law. Method is the product of society, it has subjectivity, is the superstructure of human spirit, and method of human meet up mainly from the spirit, the value of the method of content is human spirit pursuit, justice and utility is the two-basic value of law.

\section{The Development of Environmental Protection Law.}

\subsection{The Generation of Environmental Protection Laws.}

The value and development of law. Environmental law of the development of human society has experienced the stage of 1949, China promulgated a series of scattered regulations, due to the lack of connection between conservation and environmental pollution, so can't form a complete environmental protection concept; From 1973 to 1978, China formulated a series of environmental policies and guidelines, and adopted environmental pollution control measures in practice. Enactment of the environmental protection law (trial) in 1979; Then came the new environmental law in 2014.

\subsection{The Causes of Environmental Protection Laws.}

So why do people know the environment and study environmental law? In my opinion, matter determines consciousness and knowledge originates from practice. People's understanding of the environment comes from environmental degradation. From the perspective of system theory, the earth is a natural system composed of biological community and its living environment. In this system, between biological communities and their environments, and biological communities in different populations and species of matter and energy exchange between, and in the interaction and mutual influence of dynamic balance. The most basic characteristic of this system is its integrity and mutual dependence. As a member of the natural system, human beings should follow the general rules of natural systems. But since the beginning of human beings, they have refused to give in to the control of nature, constantly change and transform nature, and form a relatively independent human social system on the basis of natural system. With the progress of science and technology and productivity, human beings constantly conquer nature, human society system is growing, and natural system gradually atrophic, how to coordinate the tension between them has become a subject facing the whole of mankind. Therefore, environmental damage is the logical starting point of environmental jurisprudence. 


\section{Problems Were Exposed in Environmental Law}

In the $1980 \mathrm{~s}$, due to the environment and development is more and more regarded by the national policy makers, whether in developed countries, or developing, far-sighted people from their respective national conditions, to explore the relationship between environment and development, and seek to protect the environment, as well as the path of economic development. Can be a sustained development strategy gives the connotation of environmental protection in order to more, it asked lawmakers should renew the idea, when the environmental protection law establishment conforms to the law of environmental protection concept and value orientation, should not only focus on human interests, but also pay attention to the ecological benefit; It is necessary to maintain the social order of people and the ecological order of man and nature. It is necessary to safeguard the fairness of the generation and to consider intergenerational equity.

The environmental protection act of 1989 has exposed many deficiencies in practice. The frequent occurrence of environmental crises in China threatens the health and property safety of the people.

\section{Views of Different Scholars}

The environmental protection law of the People's Republic of China, as the basic law of environmental protection, does not play the role of protecting the environment. Therefore, the revision of the environmental protection law has become one of the hot topics in the field of environmental law in the past two years, and the discussion on its legislative purpose is particularly enthusiastic. Professor Chen autumn think: the purpose of environmental law should be "protect and improve the living environment and ecological environment, prevent pollution and destruction of environment and resources, rational development and utilization of environmental resources, safeguard human health and promote economic and social sustainable development; Professor Lu believes that environmental law is a method of sustainable development. Professor Chen believes that the current environmental protection law only focuses on the environmental rights and development rights of contemporary people, and does not involve the environmental rights and development rights of future generations. Legislative purpose shall be amended as: to seek the harmony of man and nature, maintain a clean environment and maintaining ecological balance, to ensure that our country contemporary and future generations live healthy and productive life, this law is enacted; Doctor Jin said: environmental law legislation purpose should be in does not rule out under the premise of protection of human rights and interests, and establishing equity interests between generations, to achieve economic and social sustainable development and the protection of "environmental right" of human and ecological world of "natural rights" the two goals. From the perspective of the above scholars, it can be seen that most scholars refer to sustainable development. Professor Lu explicitly mentioned that sustainable development is the value of environmental law. In the legislative purpose, professor CAI holds the direct legislative purpose of environmental law, and also marks the indirect ultimate purpose to protect human health and promote the sustainable development of economy and society.

\section{The Value Orientation of Environmental Protection Law.}

\subsection{A View of the Interests of Mankind and the Interests of Ecology.}

From the perspective of system theory, environmental law can not only start from the overall interests of mankind, but also must take into account the interests of the natural system. This is because natural systems are the preconditions for human existence, and there is no natural system or natural system to be broken, which in turn will endanger the interests of the whole mankind. In recent years, although many countries have recognized the seriousness of environmental problems and put forward the strategic thinking of sustainable development, the environment has not only failed to improve, but has a tendency to deteriorate. Basically, it is because people only pay attention to their own interests, protect the environment from their own needs, but do not recognize the results of the benefits of the natural system. Must see, natural system also has its own interests, from the individual, 
this kind of interests is the natural right of nature, including the right to survival and development of various biological, this power does not need human recognition, long before humans exist, this power is not the "heaven" gives a variety of life on earth. As a whole, this interest is the overall interest of the natural ecology, that is, to maintain the stability and harmony of the natural system, which will ultimately affect the continuation and development of the whole life of the earth.

\subsection{The Unity of the Overall Interests and the Overall Interests of the Intergenerational Ecology.}

For natural systems, due to their own can, in accordance with the evolution of the natural process of biological evolution forward, without the intervention of the human social system, it can through own metabolism to maintain a good balance of interests between generations. Therefore, in the generation and the whole of intergenerational interests balance is mainly in terms of human social system, the balancing of interests is mainly involves how to between contemporary and future generations of resources and wealth is distributed fairly. All have in common in the past, present and future of the planet's environment, current and future generations of their survival and development of environment and resources have the same choice chance and gain the same benefits. As the resources and wealth of society are in the hands of contemporary people, contemporary people are the custodian of the resources and wealth of future generations. Therefore, modern people have to consider the chance of future generations and may get the amount of resources, in the modern age, people don't when making policies and measures to improve their economic welfare and quality of life, and to a certain extent to sacrifice part of the future generations of welfare and potential opportunities, of course, it also need not by lowering the contemporary life consumption level, to enhance the young generation and future generations of unborn potential quality of life. The concept of sustainable development is of great significance for maintaining the balance of interests between generations.

\subsection{International Cooperation for Protection}

Human beings live together in the same global village, and the integrity of the earth's ecological system ultimately brings countries into the unified orbit of environmental protection, and the rise of international environmental law is inevitable. To overcome the obstacles in international environmental protection cooperation, we must pay attention to the following two points. The first is to build a new international order and establish an internationally recognized model of international development. Since the $1970 \mathrm{~s}$, the international community through the many declarations and decisions about ecological and environmental protection, such as the declaration of the human environment, the world park conference declaration, the declaration of environment and development, the declaration of the earth's environment sage meeting in Tokyo, the world's natural charter and other international documents belong to this. Although these resolutions and declarations are not binding, they reflect the principles, rules and systems of existing or emerging international environmental law. It is in these declarations and resolutions that the international community has achieved a great deal of international environmental protection treaties. Of course, we should also see that the formation and improvement of international environmental law still have a long way to go, which still requires the joint efforts of all countries in the world.

\section{Summary}

The legal value as the internal stipulation of the legal purpose is the starting point and end-result of the legal purpose, and is embedded in the arrangement of the people. Between human development and natural circulation is not irreversible conflict, maintain the harmony of human and nature, all is the survival foundation of the ecosystem, and human destructive mode of production and consumption of consumptive way is a serious threat to the foundation. Environmental law only infiltrates human beings and promotes natural steady state circulation, so as to avoid the subversion of survival basis. Environmental security, environmental justice and social development as the value pedigree of environmental law constitute the basic content and value goal of this protection. 


\section{References}

[1]. Marx and Engels complete works (volume 19) [C]. Beijing: people's publishing house, 1974. 